\title{
Information Technology for providing Electronic Identity Card to people who are living in Hambantota District in Sri Lanka
}

\author{
Kusum Priyanath Jayasinghe \\ Sri Lanka Institute of Information Technology \\ Email Address: kusumbit2016@gmail.com \\ Address: No: 07, Rathnayaka Walawwawatta, Pelawatta Road, Hapugala,Wackwella. \\ City: Galle \\ Country: Sri Lanka - Southern Province \\ Zip code: 80000 \\ DOI: 10.31364/SCIRJ/v8.i6.2020.P0620776 \\ http://dx.doi.org/10.31364/SCIRJ/v8.i6.2020.P0620776
}

\begin{abstract}
Southern Province is one of the developing province which belongs to Sri Lanka, and it consists of three districts which are Galle, Matara, and Hambantota. Hambantota district includes considerable amounts of rural areas. The Department for Registration of Persons plays a major role in national security of Sri Lanka and it does not have a proper Batch Processing Electronic Identity Card system in Sri Lankan Context. Some of the Functions are done manually; so there is huge necessity to have a proper Batch Processing Electronic Identity Card system. The Electronic Identity Card system consists of Informational based solutions to provide Identity card to people who live in Hambantota District. This system is capable of process People's data and photography and provides identity cards to poor citizens free of charge. Authorized officers of the Department for Registration of Persons in Sri Lanka can maintain all the functions of the systems and they have high priority to access the System. The actors of this system will be Grama Niladhari, authorized officers of the Pradashiya Sabaha and authorized officers of the Regional office of the Department for Registration of Persons. This Electronic Identity Card system is user-friendly and needs client less involvement. This system will do several different functions and all the transaction are done through the Internet.
\end{abstract}

Keywords: Hambantota district, Department for Registration of Persons, Batch Processing Electronic Identity Card system, Grama Niladhari, Pradashiya Sabaha

\subsection{INTRODUCTION}

Southern Province is one of the major and developing provinces which belongs to Sri Lanka are included under nine Provinces in Sri Lanka. Southern Province consists of three districts which are Galle, Matara, and Hambantota.

Hambantota District is located on the southeastern coast of Sri Lanka. It has an area of $2,593 \mathrm{~km}^{2}$ and a very dry climate. The district capital is Hambantota town; the administrative headquarters are there as well as the center of salt production. Other prominent towns include Tangalle, Ambalantota, Tissamaharama, and Beliatta. According to Figures of the Wikipedia, twelve divisional Secretariats include in Hambantota District. The largest town of the Hambantota
District is Hambantota and total Area of the Hambantota District is $2,609 \mathrm{~km}^{2}(1,007 \mathrm{sq} \mathrm{mi})$.

Hambantota District, consists of 2,496 km² (964 sq mi) land area and $113 \mathrm{~km}^{2}$ (44 sq mi) water area. According to Information of the Wikipedia the population density of the Hambantota District is $230 / \mathrm{km}^{2}$ (590/sq mi) [1].

According to Figures 2502617 number of people [2] live in southern Province and among these numbers 596,617 number of Population [2] live in Hambantota district.

In Hambantota district the highest and the lowest population is reported from Ambalantota DS (Divisional Secretariat) division $(72,943)$ and Okewela DS (Divisional Secretariat) division $(19,018)$. Urban population in Hambantota district is 31,709 . Sex ratio is defined as the number of males per 100 females. According to the data Hambantota district sex ratio (97) is higher than that ratio in Galle district (92) and Matara district (92). In calculation in percentage, urban area of the Hambantota district is 5.3 percentage and rural area in Hambantota district is 94.7 percentage. According to above mentioned Records, most of the areas are Rural, and there are no Estates which belongs to Hambantota district. In Hambantota district, urban sector is located in Hambantota and Tangalle.

In calculation in percentage of the Hambantota district, majority of the Ethnicity is Sinhalese people (97.0 Percent). And also 0.4 percent of the Tamil Ethnicity live in Hambantota district. Other ethnic groups are namely Burgher, Malay, Sri Lanka Chetty and Bharatha live in Hambantota district. According to Statistics of the Department of Census and Statistics, most of the people in Hambantota district have passed secondary education level and less belongs to Degree educational level. In calculation in percentage of the Hambantota district, 4.6 percent of people have not attended to school and 25.9 percent of people have passed the primary education. People in Hambantota district, educational level is somewhat less considerable, rather than comparing with other districts. Literacy rate is a key indicator to measure the level of reading and writing ability of People in a country. The definition of literate person is given as "If a person can both 
read and write a short statement with understanding is considered as literate". Too The Computer Literacy Rate of the people in Hambantota district is 20.0 in accordance with the Statistics of the Department of Census and Statistics [3].

According to Statistics of the Medical Statistics Unit of the Ministry of Health, Nutrition and Indigenous Medicine, represent that twelve Divisional Secretariats and one Municipal Council which is located in Hambantota District. According to the report there exists one Urban Council and ten Pradeshiya Sabhas which are attached to the Hambantota District. According to the data of the Medical Statistics Unit, there exists one Urban Council and ten Pradeshiya Sabhas which include in the Hambantota District. Too the Average Annual Growth Rate of the Hambantota district is 1.1 percent. [4].

According to figures of the reports of Performance \& Annual Accounts (District Secretariat - Hambantota), there exists 1319 a number of villages and 313 number of Schools located in Hambantota District. Too there are 7565 number of school teachers, who work in Hambantota district. [5].

The Source of the Annual Labour Force Survey reports, indicate that the 52.4 Labour force rate exists in the Hambantota district. The 254637 number of Labour force is available in Hambantota region. According to the Source of the Department of Census and Statistics, Unemployed is considered as 16,833 people who live in Hambantota District. The total extent of cultivated land of Hambantota district is 55.28 Percentage and Total extent in forest in Hambantota district is 18.31 Percentage. There available ten number of Local government institutions (Pradeshiya Sabaha), which are located in Hambantota district [6].

Also 576 number [7] of Grama Niladhari divisions are included in Hambantota District and other than that Hambantota District majority of people do cultivation for their occupation.

The Electronic Identity Card system consists of Information Technology based solutions to provide Identity card to people who live in Hambantota District. In Southern Province, Hambantota District includes a large number of rural areas. By referring to the statistics the proposed research project carries out in Hambantota District. Basically this is not a real time Electronic Identity Card providing system and it will do the Batch processing [8]. System capable of identifying and processing people's data and photo also provides Identity card to poor people free of charge. The main factor which causes to propose this system is most of the people who live in Hambantota area are less educational level and low income families. Other considerable issues such as the not interest of IT, Low level of education related to I.T and poor consumption of I.T which reasons to develop this system. To operate this system the Grama Niladharies who live in Hambantota District be the major interface in this Proposed research Project. The major functions of the Grama Niladhari of given area is to attach the data of civilization and take a photograph of civil people which using their P.C hand held Camera. In this situation the Grama Niladhari officer needs additional knowledge regarding the I.T. After that those data and photo are sent to the Department for Registration of Persons. Authorized officer will check the requirements and will direct the complete Electronic Identity Card to the Pradashiya Sabaha. The Pradashiya Sabaha officer will inform to Grama Niladhari in order to collect the two versions of Electronic Identity Card. Grama Niladhari can provide the Printable version of the Identity card and will issue Electronic Identity Card using the electronic media such as C.D or Pen Drive to the requested party.

\subsection{RESEARCH METHODOLOGY}

There are several major functions which will be included in the Electronic Identity Card system which are going to use in Hambantota District (Figure 01). By deploying an Electronic Identity Card system to Hambantota District will provide facility to get Electronic Identity Card for people who are living in Hambantota District. Authorized officer of the Department for Registration of Persons can maintain all the functions and He/She has high priority to access the system. To establish the system, I will choose the Hambantota District in southern province. According to the statistics, Department Of Animal Production and Health (Farm Registration Programme-2008) 3,901 number of Total Farms consist in Hambantota area [9]. There are several important functions which are related to the Electronic Identity Card system and the involved parties of this system will be Grama Niladhari, Authorized officers of the Pradashiya Sabaha and Authorized officers of the Department for Registration of Persons. The equipments which need to establish this system are High End P.Cs, Full Quality Cameras and High End Printers. There are three functional offices which are related to this Electronic Identity Card system. They are the office of the Grama Niladhari, office of the Pradashiya Sabaha, and the Department for Registration of Persons. The functions of the Electronic Identity Card system will capture people's personal data and photo, send those data to Department for Registration of Persons, Data and photo checking, Store the data in Database, Prepare the Identity Card, send the Identity Card to Pradashiya Sabaha. People who are living in Hambantota District send their data to the Grama Niladhari and the Grama Niladhari will get photos of the civil people using the camera. After that those data is sent to Department for Registration of Persons through the Internet. In the Department for Registration of Persons, Data checking system validate the data and send those data to Database. Then Department for Registration of Persons will create an Identity Card and send the Identity Card to Pradashiya Sabaha using email. In the location of the Pradashiya Sabaha, Authorized officers will print the Identity Card and store it in an electronic media. After that Grama Niladhari will get both format of the identity card and will Issue it to the people. It will be a major process of the Electronic Identity Card system. 


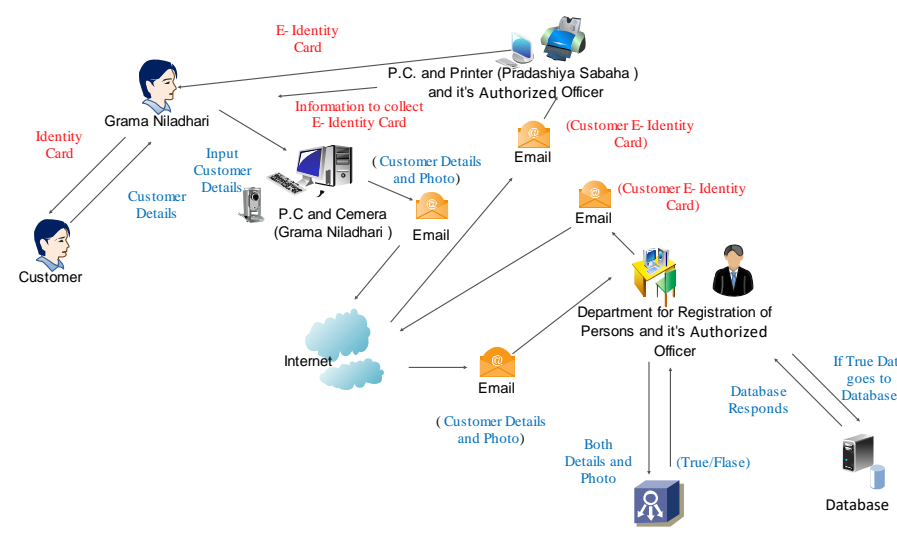

Figure 01

\subsection{RESEARCH PROBLEMS.}

Today the Department for Registration of Persons most of the operations are done manually, and people who live in rural area come to office from longer distance in order to get their Identity cards. The Department for Registration of Persons, has to put fair amount of effort to prepare the document and annual report regarding the Personal Identification. The Department for Registration of Persons in Sri Lanka plays a major role in national security of Sri Lanka and it doesn't have any batch processing [8] Electronic Identity Card system in Sri Lankan Context. Some of the functions are done manually, so there is a huge necessity to have proper batch processing [8] Electronic Identity Card system. All the people who are living in Sri Lanka must go to the Department for Registration of Persons in Sri Lanka in order to get the personal Identity card. Proposed system is capable to create Electronic Identity Card without coming to head office. In this proposed system reduces the travelling cost and saves valuable time of the rural people in Hambantota District and this proposed system provides rapid feedback to End-user. People must provide their personal details to proposed system input. Widely coverage of Internet Service Provider of the Hambantota District is more helpful to establish this system. Also newly recruited Grama Niladhari having considerable knowledge regarding I.T will be more helpful to establish this proposed system. Also they don't need to go to studio or photographer to get the photos. In this system, above mentioned functions priority will go to Grama Niladhari. This system includes three functions called Functions of the Grama Niladhari , Functions of the Pradashiya Sabaha and Functions of the Department for Registration of Persons. Very First involved party of this system is people and also final part also is people. At the beginning people give their personal data to Grama Niladhari. After that Grama Niladhari will get the photographs of the people using his camera. After completing that function Grama Niladhari will send those details to the Department for Registration of Persons using email through the internet. In the Department for Registration of Persons they validate the details through the validating system and send those data to Database. After storing the data they will prepare the Electronic Identity Card and will send it to the Pradashiya Sabaha. At the Pradashiya Sabaha, Authorized officer will print a Hardcopy of the Identity Card also prepare the Soft Copy of the Electronic Identity Card. After completing two versions of Electronic Identity Cards will be sent to Grama
Niladhari. Then Grama Niladhari will provide the two versions of Electronic Identity Card to requested people.

\subsection{RESEARCH SOLUTIONS.}

At present Hambantota district and other districts there are no Electronic based Identity cards providing system. The Electronic Identity Card system provides more efficient and reliable solutions for reducing valuable time and cost of the people, who are living in Hambantota area. According to this research project the system consists of more important functions. They are Enter the Data to the System, Validate Data, store the data in Database Create an Electronic Identity Card and finally send Electronic Identity Card to people. Inside Hambantota District, the Department for Registration of Persons identified 576 [7] of Grama Niladharies divisions and its 576 [7] number of Grama Niladharies. Inside this whole system processes are electronically and done Batch Processes [8] and there are less user involvement. Main Interfaces of this

System will be civil people who are living in Hambantota area, Grama Niladharies in Hambantota, Authorized officers of the Pradashiya Sabaha and Authorized officers of the Department for Registration of Persons in Sri Lanka. At the very first people will send his personal details such as birth certificates and /or Marriage certificates to Grama Niladhari. After that checking those certificates, he will get the photograph of the client using his camera. After accessing his personal computer and he creates an email including the personal details and photograph of the client. Here Grama Niladhari creates a Reference number and puts it in his log file and also it will be attached to email head. This reference number is given to the people to future contact regarding his Electronic Identity Card. After that this email will go to the Department for Registration of Persons in Sri Lanka through the Internet. The Authorized officer of the Department for Registration of Persons will check the data included in the email and enter data in to Data Checking System. The Data Checking System, will check all the fields and test the accuracy, reliability of the Data. If the system is satisfied with the client's details only, these details goes to Database (Department for Registration of Persons). The data will be stored in the central database of Department for Registration of Persons using the client Reference. After storing the database, authorized officer of the Department for Registration of Persons will create the Electronic Identity Card and will attach to e-mail. In this email includes the Terms and Condition, Reference Number of the client and Electronic Identity Card. Department for Registration of Persons will send this email to Pradashiya Sabaha email account by Referring Client Reference number. Pradashiya Sabaha, Authorized officers will inform the Grama Niladhari to collect Electronic Identity Card. Grama Niladhari will visit the Pradashiya Sabaha and its authorized officer will access the email account and provide two version of the Electronic Identity. After that Pradashiya Sabaha officer print the Identity Card and store the Electronic Identity Card in electronic media by using Reference Number given by the Grama Niladhari. Finally Grama Niladhari will provide the Electronic Identity Card to people and request rapid feedback. If the client is satisfied with his Identity card then he will contact Grama Niladhari and gives his comments. Then the Grama Niladhari officer gives his final confirmation to Department for 
Registration of Persons. If the client is unsatisfied Grama Niladhari will again send corrected data and Reference number to Department for Registration of Persons requesting a rapid feedback. Above mentioned functions are going around until the client is satisfied with his Electronic Identity Card.

\subsection{CONCLUSION AND FUTURE WORKS.}

Mainly Electronic Identity Card System Provides services to Hambantota district people who are living in the rural areas. This Electronic Identity Card system is user friendly and needs client's less involvement. System consists of several functional locations which are called the Grama Niladhari office, Pradashiya Sabaha Office, and office of the Department for Registration of Persons. These segments will do several different functions and all the transactions are done by using email through the Internet. In future, this system will be established over the country and observe them through one main location and identify the highest client involvement area in Sri Lanka. Here I consider on one district called Hambantota and near future I will develop proposed system all over the country (other Districts), except urban areas. Other than that it is required to Internet Speed in order to get maximum benefits of this system. In order to get maximum benefits, Interface of this systems must have some considerable knowledge regarding the I.T. Too get maximum efficiency from system, Government must provide the High End P.Cs, Camera and Special Printer to system functional units. Also government needs to provide sufficient e-medias to Pradashiya Sabaha in order to provide Electronic Identity Card to people and get maximum benefits from proposed Electronic Identity Card System.

\section{REFERENCES}

[1]Wikipedia, the free encyclopedia, Hambantota District, Sri Lanka, 2020, [Online] [Accessed 10 February 2020].Available from: https://en.wikipedia.org/wiki/Hambantota_District

[2]Wikipedia, the free encyclopedia, Southern Province, Sri Lanka, 2020, [Online] [Accessed 8 February 2020].Availablefrom:

https://en.wikipedia.org/wiki/Southern_Province,_Sri_Lanka

[3] Publication officers of the Department of Census and Statistics, 2020, Census of Population and Housing, (Final Report -Southern Province 2020), $1^{\text {st }}$ Edition, Department of Census and Statistics, Sri Lanka.

[4] Medical Statistics Unit of the Ministry of Health, Nutrition and Indigenous Medicine, 2020, Annual Health Statistics (Data Tables), $1^{\text {st }}$ Edition, Ministry of Health, Nutrition and Indigenous Medicine, Sri Lanka.

[5] Statistical Information Unit, District Secretariat Hambantota, 2020, Basic Statistical Information in the District, (Data Tables), $1^{\text {st }}$ Edition, District Secretariat Hambantota, Sri Lanka.

[6] Department of Census and Statistics,District Statistical HandBook hambantota, 2020, [Online]. [Accessed $20 \mathrm{March}$ 2020]. http://www.statistics.gov.lk/districtstathbook.asp?district=ham bantota

[7] Department of Census and Statistics, Characteristics of Housing Units and Persons Living in the Damaged Housing Units Hambantota District, 2020, [Online].[Accessed 15 March 2020].Availablefrom: http://www.statistics.gov.lk/Tsunami/final/hamban/index.htm $>$

[8]- Vitanage S, 2019, Information \& Communication Technology, $2^{\text {nd }}$ Edition, Author's publication, Sri Lanka

[9] Information and Communication Technology Agency of Sri Lanka, Average Daily Milk Production per Farm by Province and District,2020, [Online].[Accessed 20 February 2020].

Availablefrom:http://www.daph.gov.lk/web/index.php?option =com_content $\& v i e w=$ article $\& i d=61 \&$ Itemid=216\&lang=en $>$ 